\title{
Disseminated Intravascular Coagulation and the Waterhouse-Friderichsen Syndrome
}

\author{
B. FOX \\ From the Department of Histopathology, Charing Cross Hospital Medical School, London
}

\begin{abstract}
Fox, B. (1971). Archives of Disease in Childhood, 46, 680. Disseminated intravascular coagulation and the Waterhouse-Friderichsen syndrome. In a clinico-pathological study of 13 children who died with Waterhouse-Friderichsen syndrome, there were deposits of fibrin in many organs, especially the adrenal glands and the kidneys. This finding supports the hypothesis that disseminated intravascular coagulation (DIC) occurs in this syndrome. The exact role that DIC plays has not been defined; though it probab!y contributes to the severe shock and the widespread haemorrhages; the adrenal haemorrhages appear not to be due directly to DIC. The presence of DIC in the Waterhouse-Friderichsen syndrome suggests that heparin should be a logical form of treatment.
\end{abstract}

The Waterhouse-Friderichsen (W-F) syndrome is a clinico-pathological entity consisting of (a) the sudden onset of a rapidly progressive illness, (b) shock, (c) cyanosis, (d) a petechial rash, (e) death, usually within 24 hours, and (f) haemorrhages in both adrenal glands. Waterhouse (1911) described one case and reviewed the published reports, and Friderichsen (1918) described two cases and reviewed the literature. Neither of these reports added anything of significance to the full description of the syndrome by Little in 1901, who described it in 4 children and reviewed 7 other cases. Neisseria meningitidis is the organism most frequently isolated in this disease (Maclagan and Cooke, 1916; Bamatter, 1934; Banks and McCartney, 1943) but other organisms have also been found.

One of the main problems in this syndrome is the explanation of the fulminating course of the disease with irreversible shock. In spite of treatment with sulphonamides, antibiotics, and steroids, the prognosis is still extremely poor (May, 1960). It has been suggested that disseminated intravascular coagulation (DIC) is responsible for the haemorrhages, particularly in the skin and adrenal glands, and for the severe shock and cyanosis (Margaretten and McAdams, 1958; Stuber and Hitzig, 1961; McKay, 1965).

The clinical and pathological findings in 13 children with this syndrome are presented. The presence of fibrin thrombi in many organs supports

Received 24 March 1971. the concept that DIC occurs, but the adrenal haemorrhages are probably due to endotoxaemia. It is suggested that heparin should be used in the treatment of this syndrome.

\section{Case Reports}

The clinical findings are summarized in Table $I$. Cases 2, 5, and 7 had convulsions soon after the onset of the illness. Case 8 had a splenectomy for traumatic rupture at the age of 8 . The treatments are summarized in Table II. There was slight improvement during treatment in Case 5, but there was no response to treatment in any of the other cases. None of these cases was treated with heparin. The necropsy and microscopical findings are summarized in Table III. In Case 1 only one paraffin block of each adrenal gland and in Case 12 only two blocks of the left and one of the right adrenal gland were available for examination. In all the other cases paraffin blocks of the whole of both glands were prepared and serial sections examined. Sections were stained by haemalum and eosin, Mallory's phosphotungstic acid-haematoxylin, Giemsa, Gram-Weigert methods, and Perls' reaction. The extent of adrenal haemorrhage was approximately assessed from the sections (see Table III). The adrenal haemorrhages were confined to the cortices, often maximally at the level of the zona reticularis but also involving the central part of the gland in areas where the two layers of cortex are in apposition and in which there is normally no medullary tissue present. There was an apparent decrease in the number of cortical cells within the haemorrhagic areas, the remaining cells showing marked degenerative changes with pyknosis of nuclei and vacuolation of cytoplasm. 680 
TABLE I

Clinical Findings in Waterhouse-Friderichsen Syndrome

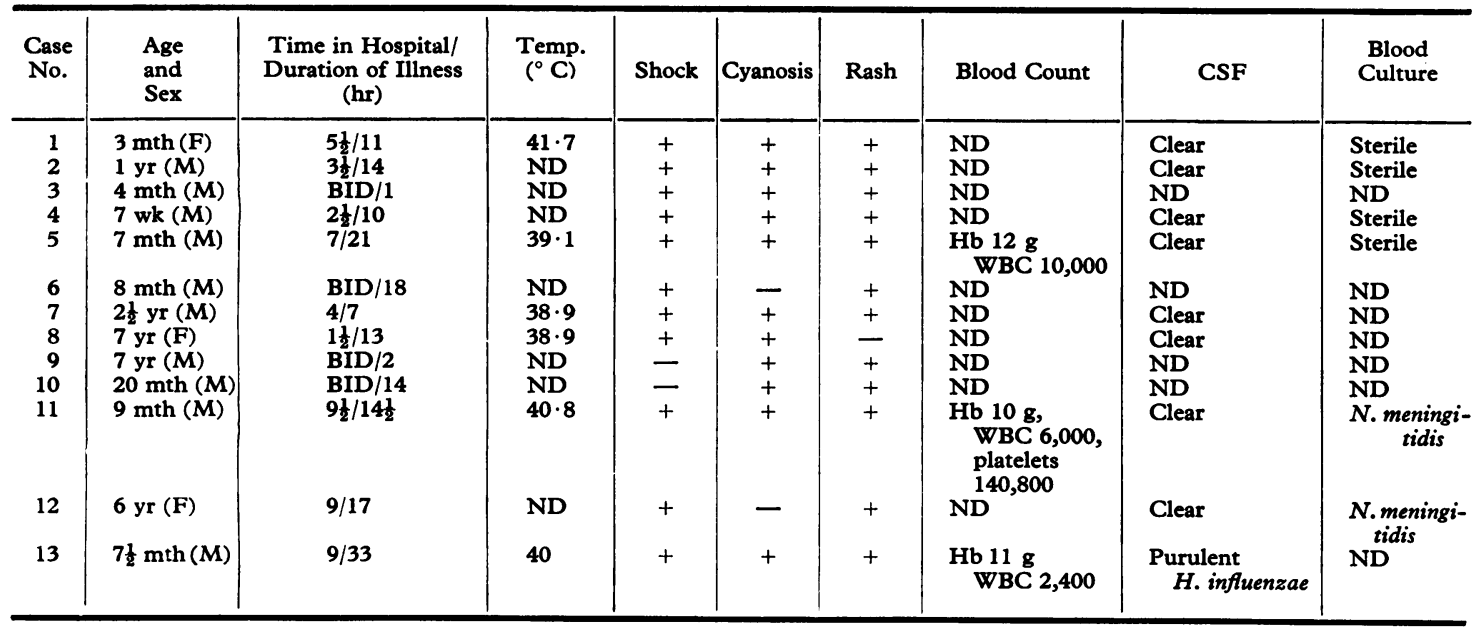

BID $=$ Dead on arrival in hospital ND $=$ Not done.

In all the glands there were varying degrees of compact cell changes and pseudotubule formation. The only other vascular changes apart from fibrin thrombi in the cortical sinusoids were platelet fibrin thrombi in branches of the central vein in Cases 2, 7, 8, and 10. There were scattered foci of neutrophil infiltration in the cortices, mainly in the areas of haemorrhage in Cases 7 and 13. No organisms were seen in the adrenal glands or skin. All of the other tissues available were examined for deposits of fibrin by staining with PTAH (see Table III). The deposits of fibrin in the kidneys were mainly in the glomerular tufts (Fig. 1) and in the liver the deposits were within the sinusoids. There was an acute focal myocarditis in Cases 9 and 12, and acute suppurative meningitis in Case 13. Early focal necrosis of the liver was present in Cases 4 and 5.

\section{Discussion}

It is important to restrict the W-F syndrome to the clinicopathological entity of a rapidly progressive disease of sudden onset with shock, cyanosis, a rash that is often petechial, and which results in death usually within 24 hours, at necropsy both adrenals being found to be haemorrhagic. If the term W-F syndrome is used in this way there is a fairly uniform pattern to the pathological changes in the adrenal glands and the other tissues. The W-F syndrome is not a synonym merely for adrenal haemorrhage or necrosis, which may be due to many diverse conditions and in which the changes in the adrenals are entirely different from those seen with the W-F syndrome.

All the descriptions of the W-F syndrome
(Little, 1901; Waterhouse, 1911; Friderichsen, 1918; Aegerter, 1936; Stiehm and Damrosch, 1966) have emphasized the fulminating nature of the disease, which is well illustrated in these cases (see Table I). The organism most commonly found is Neisseria meningitidis (Andrewes, 1906; Maclagan and Cooke, 1916; Bamatter, 1934; Martland, 1944; Hardman, 1968) and only occasionally have other organisms been isolated: $H$. influenzae (Lindsay et al., 1941; Stuber and Hitzig, 1961), haemolytic streptococcus (Stuber and Hitzig, 1961), and the pneumococcus (Parr, Shipton, and Holland, 1953; Grant et al., 1970). Montgomery and Olafsson (1960) described one case occurring with varicella. Margaretten, Nakai, and Landine (1963) described 42 cases of adrenal haemorrhage with septicaemia in which staphylococci, $H$. influenzae, and Gram-negative bacilli were isolated. Though they regarded these cases as having the W-F syndrome, it is not obvious from their description that the full clinical syndrome was present. In the present series, in only 2 out of 6 cases, in which blood cultures were examined, was $N$. meningitidis isolated, and in 1 of 9 cerebrospinal fluids examined $H$. influenzae was found, the CSF in the other cases being normal.

The isolation of meningococci is often difficult. Winkelstein et al. (1969) only found organisms in 32 of their 45 cases of meningococcal disease, and Hardman (1968) in reviewing 1,200 cases of meningococcal infection found that in nearly $25 \%$ the organism was not isolated. Though it is possible 
Treatment of the Wat 痈hon

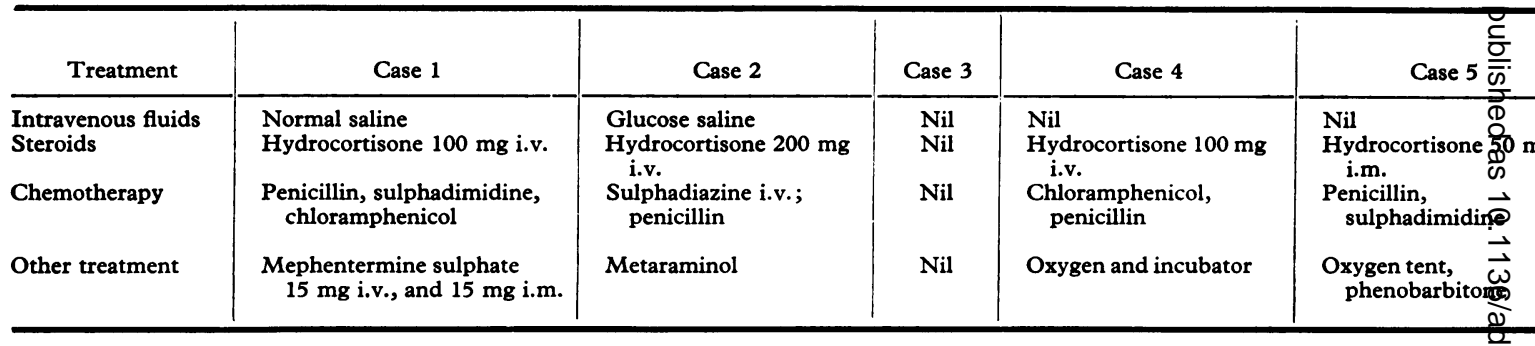

that meningococci or other organisms are not isolated for technical reasons, it may be that other as yet unidentified organisms, possibly viruses, could be responsible for the syndrome. Though it is unusual to get this syndrome with meningitis (Aegerter, 1936), it has been described with meningococcal meningitis (Andrewes, 1906; Maclagan and Cooke, 1916; Ferguson and Chapman, 1948; Hardman, 1968) and $H$. influenzae meningitis (Lindsay et al., 1941 and Case 13 in this series).

In all the cases in this series both adrenals were macroscopically haemorrhagic, but histological examination showed a variation in the amount of adrenal cortex involved (see Table II). In some sections there were large areas of uninvolved cortex adjacent to areas of haemorrhage (Fig. 2). It is important to note that the cortex alone is haemorrhagic and the medulla is completely spared (Fig. 2).
There have been many reports in which haemorrhages have been described in the medulla, and others in which there was haemorrhage in the centre of the gland and no medulla was seen (Waterhouse, 1911; Maclagan and Cooke, 1916; Aegerter, 1936; Banks and McCartney, 1943; Ferguson and Chapman, 1948). It is probable that in these cases there were haemorrhages in the central part of the gland in which medullary tissue is normally not present (Dobbie and Symington, 1966). In 10 of the present cases the whole of both glands was examined and in none of these were there any haemorrhages in the medulla.

In this syndrome the explanation of the severe shock and the rapid course of the disease are the main clinicopathological problems. For many years it was thought that they were due to the adrenal haemorrhages with subsequent adrenal failure

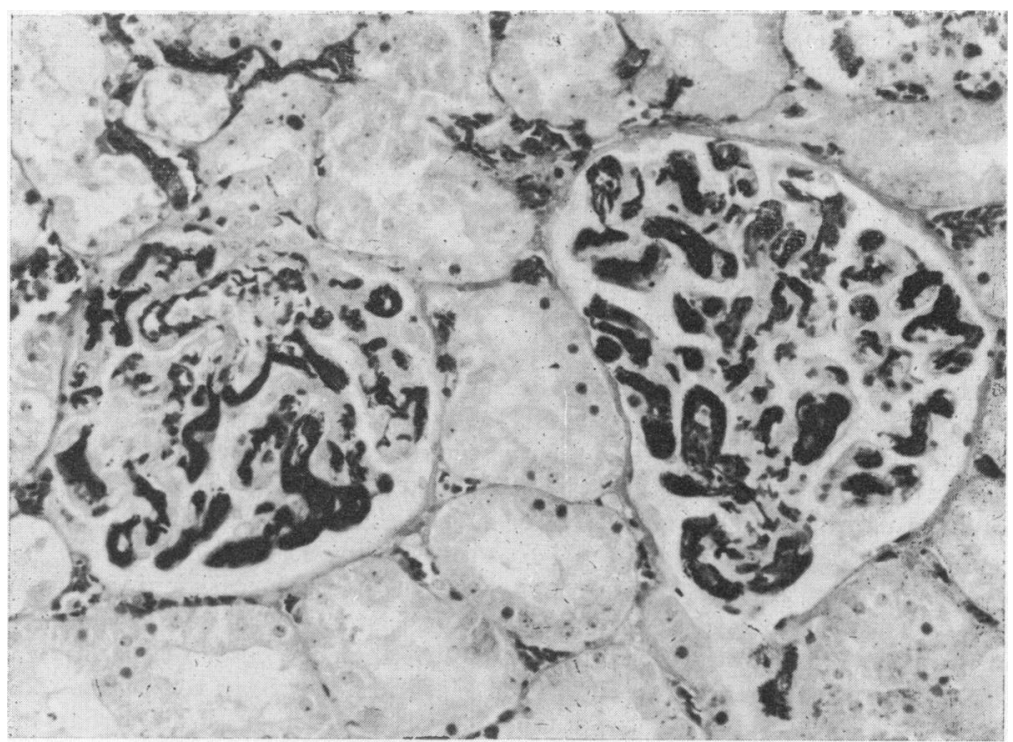

FIG. 1.-Case 7. Deposits of fibrin in glomerular tufts. (Phosphotungstic acid haematoxylin $\times 190$.) 
¿derichsen Syndrome

\begin{tabular}{|c|c|c|c|c|c|}
\hline Case 6 & Case 7 & $\begin{array}{c}\text { Cases 8, } \\
9,10\end{array}$ & Case 11 & Case 12 & Case 13 \\
\hline $\begin{array}{l}\mathrm{Nil} \\
\mathrm{Nil}\end{array}$ & $\begin{array}{l}\text { Dextrose saline } \\
\text { Hydrocortisone } 100 \mathrm{mg} \\
\quad \text { i.v. (twice in } 1 \mathrm{hr} \text { ) }\end{array}$ & $\begin{array}{l}\text { Nil } \\
\text { Nil }\end{array}$ & $\begin{array}{l}\text { Nil } \\
\text { Hydrocortisone } 100 \mathrm{mg} \\
\text { i.v. }\end{array}$ & $\begin{array}{l}\text { Nil } \\
\text { Hydrocortisone } 250 \mathrm{mg} \text { i.v. }\end{array}$ & $\begin{array}{l}\text { Plasma dextrose, saline } \\
\text { Hydrocortisone } 100 \mathrm{mg} \text { i.v. } \\
\text { (twice in } 4 \mathrm{hr} \text { ) }\end{array}$ \\
\hline Nil & Kanamycin & Nil & Penicillin & $\begin{array}{l}\text { Penicillin, chloramphenicol } \\
\text { i.v.; sulphadiazine i.v. }\end{array}$ & $\begin{array}{l}\text { Sulphadiazine, } \\
\text { chloramphenicol }\end{array}$ \\
\hline Nil & Nil & Nil & Nil & Nil & Phenobarbitone \\
\hline
\end{tabular}

(Maclagan and Cooke, 1916; Friderichsen, 1918; Banks and McCartney, 1943; Cosgriff, 1944; Nelson and Goldstein, 1951). However it has been suggested that too much emphasis has been placed on the role of the adrenals in this syndrome (Aegerter, 1936; Williams, 1942; Björklund, 1953). In the present series there was no correlation between the extent of adrenal haemorrhages and the clinical state, and there was no response to treatment with steroids. These findings support the idea that acute adrenal failure plays little part in the production of this syndrome (May, 1960; Symington, 1969). It has been suggested that the severe 'irreversible' shock, adrenal and other haemorrhages found are due to DIC (Margaretten and McAdams, 1958; Stuber and Hitzig, 1961; McKay, 1965). DIC is due to the in vivo activation of clotting mechanisms and may produce profound shock, a haemorrhagic state, and the deposition of fibrin thrombi in many organs (Hjort and Rapaport, 1965; McKay, 1965). The presence of fibrin thrombi in many organs in this series (Table III) supports the concept that DIC occurs, but the exact role that it plays in the pathogenesis of the syndrome is not clear. The main cause of this difficulty is that in this syndrome it has been claimed that DIC is due to endotoxaemia (Hjort and Rapaport, 1965) and it is difficult to assess which effects are due to endotoxaemia alone and which to the concurrent DIC. Margaretten and McAdams (1958), McKay (1965), and Hjort and Rapaport (1965) have thought that blockage of the adrenal cortical sinusoids, which occurs with DIC, caused the adrenal haemorrhage. However, the histo-

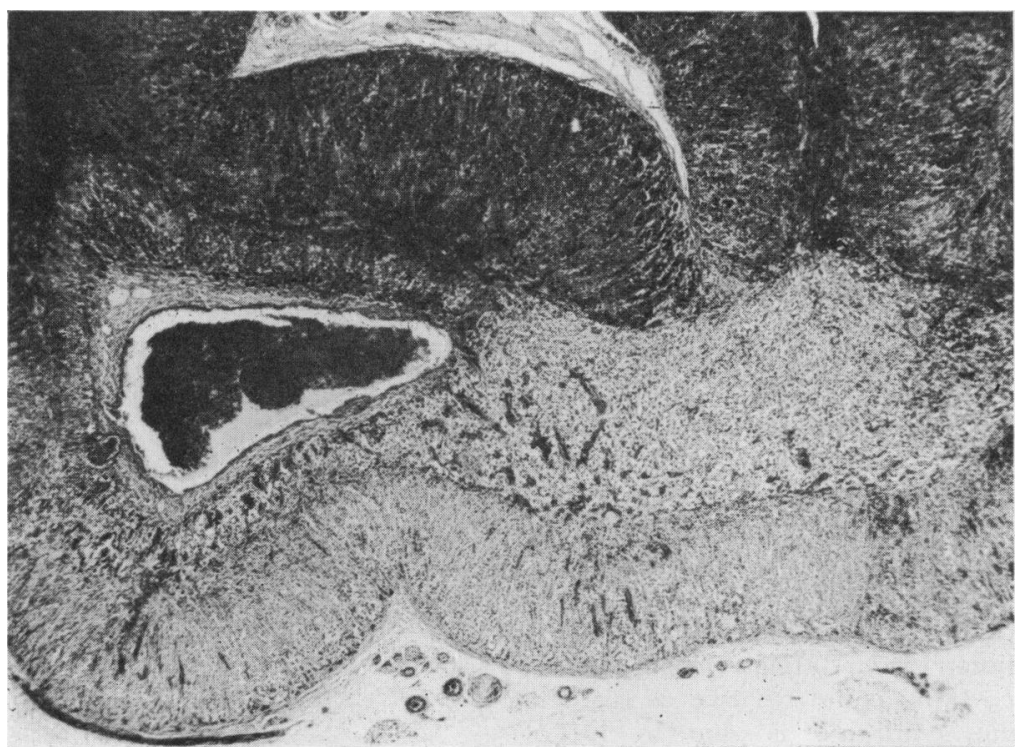

FIG. 2.-Case 2. Adrenal gland with haemorrhage in area of cortex at the top of the photograph; the medulla in the middle, and the area of cortex at the bottom are free of haemorrhage. $(\times 9$. 
TABLE III

Necropsy Findings

\begin{tabular}{|c|c|c|c|c|c|}
\hline \multirow[b]{2}{*}{$\begin{array}{l}\text { Case } \\
\text { No. }\end{array}$} & \multicolumn{2}{|c|}{ Adrenal Glands } & \multirow[b]{2}{*}{ Sites of Deposits of Fibrin } & \multirow[b]{2}{*}{ Haemorrhages } & \multirow[b]{2}{*}{$\begin{array}{c}\text { Other Organs Examined } \\
\text { Microscopically }\end{array}$} \\
\hline & $\begin{array}{c}\text { Cortical } \\
\text { Haemorrhage } \\
\text { Right/Left (\%) }\end{array}$ & $\begin{array}{l}\text { Fibrin } \\
\text { Thrombi in } \\
\text { Sinusoids }\end{array}$ & & & \\
\hline $\begin{array}{l}1 \\
2 \\
3 \\
4\end{array}$ & $\begin{array}{l}25 / 25 \\
90 / 90 \\
80 / 80 \\
50 / 80\end{array}$ & $\begin{array}{l}- \\
+ \\
+\end{array}$ & $\begin{array}{l}\text { Lung } \\
\text { Kidneys, liver, skin } \\
\text { Kidneys } \\
\text { Kidneys, liver, lungs }\end{array}$ & 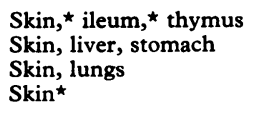 & $\begin{array}{l}\text { Thymus } \\
\text { Spleen, lungs, brain } \\
\text { Heart, liver } \\
\text { Spleen, oesophagus, thymus, } \\
\text { brain }\end{array}$ \\
\hline $\begin{array}{l}5 \\
6 \\
7\end{array}$ & $\begin{array}{l}80 / 70 \\
40 / 40 \\
60 / 60\end{array}$ & $\begin{array}{l}+ \\
+ \\
+\end{array}$ & $\begin{array}{l}\text { Kidneys, liver, brain, skin } \\
\text { Liver, spleen, trachea, skin } \\
\text { Kidneys, liver, brain, } \\
\text { pancreas, thymus }\end{array}$ & $\begin{array}{l}\text { Skin, liver, brain, spleen } \\
\text { Skin, kidneys, heart } \\
\text { Skin }\end{array}$ & $\begin{array}{l}\text { Lung, thymus } \\
\text { Lung } \\
\text { Spleen }\end{array}$ \\
\hline $\begin{array}{l}8 \\
9\end{array}$ & $\begin{array}{l}75 / 60 \\
75 / 60\end{array}$ & $\begin{array}{l}+ \\
+\end{array}$ & $\begin{array}{l}\text { Kidneys } \\
\text { Kidneys, liver, spleen, lungs, } \\
\text { skin, brain }\end{array}$ & Skin & $\begin{array}{l}\text { Liver, pancreas, lymph node } \\
\text { Heart, lymph node, } \\
\text { diaphragm }\end{array}$ \\
\hline 10 & $80 / 90$ & + & Kidneys, brain & Skin $\star$ & Liver, lung, spleen \\
\hline 11 & $90 / 80$ & + & Kidneys, liver, brain, skin & Skin, heart & $\begin{array}{l}\text { Lungs, spleen, thymus, } \\
\text { testes, lymph node }\end{array}$ \\
\hline 12 & $60 / 50$ & + & Kidneys, liver, pituitary & Skin, „ lungs & $\begin{array}{l}\text { Heart, spleen, thymus, bone } \\
\text { marrow }\end{array}$ \\
\hline 13 & $90 / 90$ & + & $\begin{array}{l}\text { Kidneys, liver, jejunum, } \\
\text { stomach, lymph node, } \\
\text { pancreas, lungs, tongue, } \\
\text { brain, skin }\end{array}$ & Skin & Bladder, testes \\
\hline
\end{tabular}

^Not examined microscopically.

logical evidence in this series is against this hypothesis; thus there is no apparent correlation between the extent of cortical haemorrhages and the distribution of the sinusoidal thrombi, there are many areas in which there are few fibrin thrombi, and there are fibrin thrombi in the sinusoids in the non-haemorrhagic cortices. Levin and Cluff (1965), from their experimental studies, suggested that the adrenal haemorrhages in humans with W-F syndrome were due to the direct action of endotoxin on the 'stressed' adrenal cortex. The presence of degenerate cortical cells in the areas of haemorrhage, and the changes of stress in the cortices (compact cells and pseudotubules) in these cases support their hypothesis. The presence of fibrin thrombi in the sinusoid in the adrenals could be coincidental, and though it is due to DIC, it is not the cause of the adrenal haemorrhages. As it has been shown that heparin prevents DIC occurring in animals (Good and Thomas, 1953) and will prevent its spread in man (Merskey et al., 1964; Corrigan, Ray, and May, 1968), the observation that heparin is of therapeutic value in the W-F syndrome (Abildgaard et al., 1967; McGehee, Rapaport, and Hjort, 1967; Corrigan et al., 1968; Winkelstein et al., 1969) could be used as further evidence that the syndrome is due to DIC. Furthermore, it is appropriate to emphasize the practical importance of the possible therapeutic value of heparin in this syndrome. Heparin should be used in addition to other therapeutic procedures in patients with suspected W-F syndrome in which DIC is thought to be occurring. While there are debatable theoretical arguments against the use of cortisone in the W-F syndrome if it is due to DIC (May, 1960; Stuber and Hitzig, 1961), the use of this hormone in conjunction with heparin is to be encouraged.

In this series of cases with the W-F syndrome there is strong evidence that DIC occurs. Treatment of this complication with heparin should lead to an improvement in the prognosis of this usually fatal syndrome.

I wish to thank the physicians under whose care these patients were admitted to hospital for allowing me to use their clinical notes; and Mr. R. S. Barnett for the photomicrographs.

\section{REFERENCES}

Abildgaard, C. F., Corrigan, J. J., Seeler, R. A., Simone, J. V., and Schulman, I. (1967). Meningococcemia associated with intravascular coagulation. Pediatrics, 40, 78.

Aegerter, E. E. (1936). The Waterhouse-Friderichsen syndrome. A review of the literature and a report of two cases. Fournal of the American Medical Association, 106, 1715.

Andrewes, F. W. (1906). A case of acute meningococcal septicaemia. Lancet, 1, 1172.

Bamatter, F. (1934). Fulminante Meningokokkensepsis zur Ätiologie des Syndroms on Waterhouse-Friderichsen. fahrbuch für Kinderheilkunde, 142, 129.

Banks, H. S., and McCartney, J. E. (1943). Meningococcal adrenal syndromes and lesions. Lancet, $1,771$. 


\section{Disseminated Intravascular Coagulation and the Waterhouse-Friderichsen Syndrome}

Björklund, S. I. (1953). The Waterhouse-Friderichsen syndrome. Acta Paediatrica, 42, 77.

Corrigan, J. J., Jr., Ray, W. L., and May, N. (1968). Changes in the blood coagulation system associated with septicemia. New England Fournal of Medicine, $279,851$.

Cosgriff, S. W. (1944). Waterhouse-Friderichsen syndrome: observations on associa ted adrenal insufficiency and report of four cases. Annals of Internal Medicine, 21, 247.

Dobbie, J. W., and Symington, T. (1966). The human adrenal gland with special reference to the vasculature. Fournal of Endocrinology, 34, 479.

Ferguson, J. H., and Chapman, O. D. (1948). Fulminating meningococcic infections and the so-called Waterhouse-Friderichsen syndrome. American fournal of Pathology, 24, 763.

Friderichsen, C. (1918). Nebennierenapoplexie bei kleinen Kindern. Fahrbuch für Kinderheilkunde, 87, 109.

Good, R. A., and Thomas, L. (1953). Studies on generalized Shwartzman reactions. IV. Prevention of the local and generalized Shwartzman reactions with heparin. Fournal of Experimental Medicine, 97, 871

Grant, M. D., Horowitz, H. I., Lorian, V., and Brodman, H. R. (1970). Waterhouse-Friderichsen syndrome induced by pneumococcemic shock. Fournal of the American Medical Association, 212, 1373.

Hardman, J. M. (1968). Fatal meningococcal infections: the changing pathologic picture in the $60 \mathrm{~s}$. Military Medicine, 133, 951 .

Hjort, P. F., and Rapaport, S. I. (1965). Shwartzman reaction: pathogenetic mechanisms and clinical manifestations. Annual Review of Medicine, 16, 135.

Levin, J. and Cluff, L. E. (1965). Endotoxaemia and adrenal hemorrhage: a mechanism for the Waterhouse-Friderichsen syndrome. Fournal of Experimental Medicine, 121, 247.

Lindsay, J. W., Rice, E. C., Selinger, M. A., and Robins, L. (1941) The Waterhouse-Friderichsen syndrome. Acute bilateral suprarenal hemorrhage. American fournal of the Medical Sciences, 201, 263.

Little, E. G. (1901). Cases of purpura, ending fatally, associated with haemorrhage into the suprarenal capsules. British fournal of Dermatology, 13, 445.

McGehee, W. G., Rapaport, S. I., and Hjort, P. F. (1967). Intravascular coagulation in fulminant meningococcemia. Annals of Internal Medicine, 67, 250.

McKay, D. G. (1965). Disseminated Intravascular Coagulation: An Intermediary Mechanism of Disease, p. 85. Hoebe, New York.

Maclagan, P. W., and Cooke, W. E. (1916). The fulminating type of cerebo-spinal fever: pathology and cause of death. Lancet, $2,1054$.

Margaretten, W., and McAdams, A. J. (1958). An appraisal of fulminant meningococcemia with reference to the Shwartzman phenomenon. American fournal of Medicine, 25, 868.

Margaretten, W., Nakai, H., and Landing, B. H. (1963). Septicemic adrenal hemorrhage. American fournal of Diseases of Children, $105,346$.

Martland, H. S. (1944). Fulminating meningococcic infection with bilateral massive adrenal hemorrhage (the WaterhouseFriderichsen syndrome) with special reference to the pathology, the medicolegal aspects and the incidence in adults. Archives of Pathology, 37, 147.

May, C. D. (1960). Circulatory failure (shock) in fulminant meningococcal infection: an enquiry into the pathogenesis as an approach to rational therapy. Pediatrics, 25, 316.

Merskey, C., Johnson, A. J., Pert, J. H., and Wohl, H. (1964). Pathogenesis of fibrinolysis in defibrination syndrome: effect of heparin administration. Blood, 24, 701.

Montgomery, R. R., and Olafsson, M. (1960). WaterhouseFriderichsen syndrome in varicella. Annals of Internal Medicine, 53, 576.

Nelson, J., and Goldstein, N. (1951). Nature of WaterhouseFriderichsen syndrome. Report of a case with successful treatment with cortisone. Fournal of the American Medical Association, 146, 1193.

Parr, L. J. A., Shipton, E. A., and Holland, E. H. (1953). A fatal case of Still's disease associated with Waterhouse-Friderichsen syndrome due to pneumococcal septicaemia. Medical fournal of Australia, 1, 300.

Stiehm, E. R., and Damrosch, D. S. (1966). Factors in the prognosis of meningococcal infection. Fournal of Pediatrics, 68, 457

Stuber, H. W., and Hitzig, W. H. (1961). Zur Pathogenese und Therapie des Waterhouse-Friderichsen-Syndroms. Beziehungen zum Sanarelli-Shwartzman-Phänomen. Schweizerische medizinische Wochenschrift, 91, 1612.

Symington, T. (1969). Functional Pathology of the Human Adrenal Gland, p. 174. Livingstone, Edinburgh.

Waterhouse, R. (1911). A case of suprarenal apoplexy. Lancet, $1,577$.

Williams, H. (1942). Meningococcal infections in infancy and childhood. II. Meningococcal septicaemia, with special reference to adrenal apoplexy or the Waterhouse-Friderichsen syndrome. Medical fournal of Australia, 2, 557.

Winkelstein, A., Songster, C. L., Caras, T. S., Berman, H. H., and West, W. L. (1969). Fulminant meningococcemia and disseminated intravascular coagulation. Archives of Internal Medicine, 124, 55.

Correspondence to Dr. B. Fox, Department of Histopathology, Charing Cross Hospital Medical School, London WC2N $4 \mathrm{HH}$. 